\title{
INFLUENCE OF MOLYBDENUM DOSES IN INOCULATION AND MINERAL FERTILIZATION IN COWPEA BEANS
}

\author{
INFLUENCIA DE DOSES DE MOLIBDENNIO NA INOCULAÇÃO E NA \\ FERTILIZAÇÃO NITROGENADA EM FEIJÃO CAUPI
}

\author{
Daniele Cabral MICHEL ${ }^{1 *}$; Isabela Cristina Filardi VASQUES ${ }^{2}$; \\ Geisislaine do Carmo Reis ARAÚJO ${ }^{3}$; Jordana Luísa de CASTRO'; \\ Lucas Lenin Resende de ASSIS ${ }^{1}$; Rayner Hugo Cassa Louzada dos REIS ${ }^{1}$; \\ Maria Lígia de Souza SILVA ${ }^{1}$; Valdemar FAQUIM ${ }^{1}$
}

1. Departamento de Ciência do Solo, Universidade Federal de Lavras, Lavras, MG, Brasil. danielecamichel@gmail.com;

2. Departamento de Solos e Nutrição de Plantas, Universidade Federal de Viçosa, Viçosa, MG, Brasil.

3. Departamento de Engenharia Florestal, Universidade Federal de Lavras, Lavras, MG, Brasil.

\begin{abstract}
In some leguminous plants, associations with nitrogen-fixing microorganisms allow their nutrition with nitrogen $(\mathrm{N})$ from the atmosphere. This process is known as Biological Nitrogen Fixation (BNF), where through nitrogenase enzymes, $\mathrm{N}_{2}$ is converted to an available form. This process can replace in part, or in total, nitrogen fertilizers. Cowpea bean is a legume species that is recognized for its high capacity to carry out BNF. In the last decades, studies have encouraged small farmers from north and northeast Brazil to use inoculants with rhizobia species since the results of researches have demonstrated that inoculation is an interesting strategy to improve cowpea production. Considering the specific function of molybdenum (Mo) in the $\mathrm{N}$ assimilation, different doses of Mo were tested in this study in order to find doses that could improve and enhance BNF. Therefore, this study aimed to compare nitrogen fertilization and BNF in the N assimilation by plants with different Mo doses. Inoculation was performed with the strains UFLA 03-84 and INPA 03-11B. Doses of Mo were applied in seeds and each pot contained five seeds. Thirty-five days after germination, the plants were analyzed for shoot dry matter and fresh matter, N contents and accumulation, as well as the SoilPlant Analysis Development (SPAD) Index and nodulation in inoculated plants. The different doses of Mo and also the nodulation treatments did not show significant differences in the contents of $\mathrm{N}$. Plants with $\mathrm{N}$ fertilization had significant higher shoot dry matter and root dry matter production, in addition to higher $\mathrm{N}$ foliar contents and $\mathrm{N}$ accumulation. Therefore, BNF was not as efficient as nitrogen fertilization in the evaluated experimental conditions using cowpea beans.
\end{abstract}

\section{KEYWORDS: Vigna unguiculata L.. Micronutrient. Bradyrhizobium.}

\section{INTRODUCTION}

In some Brazilian areas, part of the daily food production is based on cowpea beans (Vigna unguiculata L). This leguminous plant has a production potential in the order of $6000 \mathrm{~kg} \mathrm{ha}^{-1}$. However, it is important to emphasize that as any other crop, it requires proper soil fertilization management to ensure high productivity. Cowpea beans are extremely efficient in performing symbiosis with nitrogen-fixing bacteria (ZILLI et al., 2006).

Nitrogen $(\mathrm{N})$ is a mineral with a complex cycle, being highly demanded by plants as the most limiting nutrient in plant growth. Low $\mathrm{N}$ contents in soils, plants with a short cycle and roots growth in the surface layer can increase the demand for $\mathrm{N}$, especially for leguminous plants (SOARES et al., 2016). To supply the need for N, some farmers have decreased the use of mineral fertilization, replacing it with atmospheric $\mathrm{N}$-fixing bacteria. In the process of mutual symbiosis between bacteria and leguminous plants (in this case, Bradyrhizobium), the biological nitrogen fixation (BNF) is considered a key technique to provide $\mathrm{N}$ to plants (COOPER; SCHERER, 2012), especially regarding tropical legumes (CASTRO et al., 2017; COSTA et al., 2017a, 2017b; FERREIRA et al., 2013; LIMA; PEREIRA; MOREIRA, 2005; RUFINI et al., 2016).

The contribution of BNF in soybean (Glycine max) and common bean is already well stated and represents a significant economy regarding the use of nitrogen fertilizers. However, this technology has not been widely used since cowpea beans are mostly produced by small farmers. Therefore, considering the potential of BNF to be exploited and the intrinsic characteristics of this culture in interacting with $\mathrm{N}$-fixing 
Influence of molybdenum...

microorganisms (RUMJANEK et al., 2005; VIEIRA et al., 2010), some researchers have invested efforts in this direction (CASTRO et al., 2017; COSTA et al., 2014a, 2014b; FARIAS et al., 2016; SOARES et al., 2006), in order to make this technology accessible to any producer.

Nutrients such as cobalt $(\mathrm{Co})$, iron $(\mathrm{Fe})$, and molybdenum (Mo) in soils are essential for nitrogen-fixing microorganisms. For example, due to its role as a cofactor of nitrogenase and nitrate reductase, Mo is essential for the functioning of the enzymes in the $\mathrm{N}$ metabolism (BROADLEY et al., 2012). The form that $\mathrm{N}$ is supplied to plants and its metabolism is highly connected to the requirement of Mo and its functions in some leguminous plants (BROADLEY et al., 2012).

Several studies have demonstrated that Mo application in soils shows positive responses in some plants (GUPTA, 1981; KUBOTA, 2006), since this micronutrient is generally found in low levels in soils. According to some authors (FREIRE FILHO et al., 2005; JACOB-NETO; THOMAS; FRANCO, 1988), the greater availability of Mo occurs either by the application of limestone that promotes the reduction of the adsorption effect or by the application of this nutrient, which promotes significant increases of BNF.

Therefore, this study aimed to compare the efficiency of different doses of Mo $(0,0.05,0.1,0.2$, and $0.4 \mathrm{mg} \mathrm{pot}^{-1}$ ) in the BNF process, using lime to increase soil $\mathrm{pH}$, and consequently increasing $\mathrm{Mo}$ availability. The fixation of $\mathrm{N}_{2}$ was provided by the following strains: UFLA 03-84 and INPA 03-11B. Treatments using $\mathrm{N}$ fertilization were also tested in order to measure the efficient the nitrogen fixation. The doses of Mo were tested in the treatments with and without $\mathrm{N}$ addition. The strains were added the treatments without the addition of $\mathrm{N}$, since this nutrient inhibit the activity of $\mathrm{N}$-fixing bacteria.

This study aimed to find an adequate Mo dose in order to allow a better biological nitrogen fertilization performance.

\section{MATERIAL AND METHODS}

\section{Soil sampling and preparation}

The experiment was conducted under greenhouse conditions, using a clayey Red-Yellow Latosol, which was collected in a region that presents a transition Cwa-Cwb climate (according to the Köppen classification) (ANTUNES, 1986), with annual average temperature of $19.6{ }^{\circ} \mathrm{C}$, annual average precipitation of $1511 \mathrm{~mm}$, annual air
MICHEL, D. C. et al.

humidity average of $76.2 \%$, and annual evaporation of $901.1 \mathrm{~mm}$ (ALVARES et al., 2013). The soil was collected from the 0-0.2-m layer, in a mountainous area with the following geographic coordinates: $21^{\circ} 17^{\prime} 16^{\prime \prime} \mathrm{S}$ and $44^{\circ} 48^{\prime} 07^{\prime \prime} \mathrm{W}$.

The soil was air-dried and passed through a 2-mm sieve to obtain air-dried fine earth (ADFE). The soil samples were sterilized twice with $24 \mathrm{~h}$ intervals between each sterilization process in order to remove soil microorganisms, especially native bacteria strains that could fix atmospheric $\mathrm{N}$ and compete with the inoculated bacteria. After sterilization, the soil was analyzed for its physical and chemical attributes (Table 1). Limestone (2.13 g $\operatorname{pot}^{-1}$ ) and fertilizers (MALAVOLTA, 1980) were applied in order to allow plant growth. The fertilization was divided into three stages: five, 12 and 19 days after cultivation. In the first stage, P, K, $\mathrm{Mg}, \mathrm{S}$, and $\mathrm{N}$ (according to the treatments that receive it) were applied. In the second stage: N, K, and $\mathrm{S}$ were applied and the third stage, $\mathrm{N}, \mathrm{K}, \mathrm{B}, \mathrm{Zn}$, $\mathrm{Mn}, \mathrm{Fe}$, and $\mathrm{Cu}$ were added. The cowpea bean cultivar Cauamé was used in this study.

\section{Inoculation preparation}

The experiment followed a randomized complete block design, with three replications. The factorial scheme consisted of five doses of Mo $(0$, $0.05,0.1,0.2$, and $\left.0.4 \mathrm{mg} \mathrm{L}^{-1}\right)$ and two types of $\mathrm{N}$ application: fertilization with ammonium nitrate and inoculation with Bradyrhizobium bacteria strains. The seeds were treated with a molybdenum acid solution, leaving them soaked in the solution for 30 min. Then, the seeds were air-dried prior to cultivation.

The inocula were prepared with strains from the Bradyrhizobium genus, specifically UFLA 03-84 (COSTA et al., 2019) and INPA 03-11B (GUIMARÃES et al., 2015), which are recommended as a leguminous inoculant for cowpea. The inocula were grown in Petri plates, in YMA (VINCENT, 1970), from five to seven days and, as they showed enough growth, they were transferred to Erlenmeyer glasses filled with the same medium but without Agar (YM). After five days, $1 \mathrm{~mL}$ of the inoculum was applied in cowpea beans seeds, consisting of a mix of both strains.

Pots of $4 \mathrm{dm}^{3}$ were used, with 5 seeds in each pot. Twenty-five days after germination the plants were harvested, leaving three plants per pot. After germination, plants were cultivated for 35 days, when it was expected a maximum nodule activity. 
Table 1. Soil chemical and physical attributes after sterilization.

\begin{tabular}{|c|c|c|}
\hline Layer & & $0-20 \mathrm{~cm}$ \\
\hline $\mathrm{pH}\left(\mathrm{H}_{2} \mathrm{O}\right)$ & & 4.9 \\
\hline $\mathrm{K}$ & \multirow{8}{*}{$\mathrm{mg} \mathrm{dm} \mathrm{m}^{-3}$} & 26 \\
\hline $\mathrm{P}$ & & 0.28 \\
\hline $\mathrm{Zn}$ & & 1.37 \\
\hline $\mathrm{Fe}$ & & 12 \\
\hline $\mathrm{Mn}$ & & 1.26 \\
\hline $\mathrm{Cu}$ & & 0.61 \\
\hline B & & 0.24 \\
\hline $\mathrm{S}$ & & 7.03 \\
\hline $\mathrm{Ca}$ & \multirow{5}{*}{$\mathrm{cmol}_{\mathrm{c}} \mathrm{dm}^{-3}$} & 0.3 \\
\hline $\mathrm{Mg}$ & & 0.1 \\
\hline $\mathrm{Al}$ & & 0.3 \\
\hline $\mathrm{H}+\mathrm{AL}$ & & 2.01 \\
\hline${ }^{*} \mathrm{CEC}(\mathrm{pH} 7.0)$ & & 2.55 \\
\hline $\mathrm{M}$ & \multirow{2}{*}{$\%$} & 39 \\
\hline V & & 18.3 \\
\hline **O.M. & \multirow{4}{*}{ dag $\mathrm{kg}^{-1}$} & 0.54 \\
\hline Sand & & 65 \\
\hline Clay & & 32 \\
\hline Silt & & 3 \\
\hline
\end{tabular}

*CEC: Cation Exchange capacity, ${ }^{* *} \mathrm{O}$. M.: organic matter.

\section{Experiment Evaluation}

The analyzed variables were: number of nodules, nodules dry matter (NDM), shoot dry matter (SDM), root dry matter (RDM), $\mathrm{N}$ foliar content and SPAD index. Thirty-five days after the emergence of plants, the SPAD index was measured using the portable equipment SPAD502, in the leaves located in the upper third part of each plant. Studies have shown that the SPAD Index is an important predictor of the $\mathrm{N}$ contents in leaves (SIMIL et al., 2019) as well as for the chlorophyll contents (BOYDSTON et al., 2018). After that, the plants were removed from the pots and the root nodules were quantified.

The material was separated into shoot, root, and nodules. They were conditioned in properly identified paper bags and oven dried at $70 \pm 5{ }^{\circ} \mathrm{C}$ for five days until reaching constant weight, when they were weighed for dry matter quantification.

The semi-micro Kjeldahl methodology was used to evaluate the $\mathrm{N}$ foliar contents. The shoots were grounded and $1 \mathrm{~g}$ of each sample was used in the procedure.

\section{Statistical Analysis}

The data were analyzed using the SISVAR software, version 5.6 (FERREIRA, 2011). The Shapiro Wilk test was conducted to verify data normality and, whenever necessary, the data were transformed according to the formula $(\mathrm{X}+0.5) 0.5$ in order to meet the assumptions of the analysis. The data was also submitted to analysis of variance using the Scot Knott test with 5\% probability.

\section{RESULTS AND DISCUSSION}

The initial objective of the study was to identify one or more doses of Mo that could optimize and increase the $\mathrm{N}$ contents in the plants from the BNF, considering the application of limestone as a facilitating process, since it promotes the increase of soil $\mathrm{pH}$. At high $\mathrm{pH}$ conditions, Mo becomes more available. This hypothesis was initially reinforced by other studies, such as Ma et al. (2018), who obtained results indicating increased $\mathrm{N}$ uptake by Mo application and even noticed that it may be beneficial for subsequent crops, although there are few studies on availability for subsequent crops. However, it was observed that in the different interactions between the statistical variables (SDM, RDM, $\mathrm{N}$ accumulation, number and dry weight of nodules, $\mathrm{N}$ foliar content and SPAD index) (Table 2 ), there were no significant effects of different doses of Mo. The interaction between Mo doses and nitrogen fertilization/bacteria inoculation also did not reveal significant differences in any evaluated characteristics. 
Table 2. Analysis of variance for the number of nodules, SDM, RDM, NDM, N content and SPAD index.

\begin{tabular}{cccccccc}
\hline Variation & FD & Number of nodules & SDM & RDM & NDM & N content & SPAD Index \\
\hline Block & 2 & 7.217 & 3.610 & 0.011 & 0.002 & 1.602 & 36.888 \\
Mo doses & 4 & 1.174 & 0.585 & 0.009 & 0.0006 & 0.265 & 15.673 \\
N fertilization & 1 & - & $70.605^{*}$ & $0.090^{*}$ & - & $65.069^{*}$ & 48.794 \\
Interaction & 4 & - & 0.585 & 0.312 & - & 0.151 & 37.948 \\
Residual & 18 & 2.375 & 1.461 & 0.011 & 0.0004 & 0.403 & 31.718 \\
Mean & - & 3.777 & 2.241 & 0.956 & 0.073 & 7.32 & 40.582 \\
\hline VC\% & - & 40.80 & 53.94 & 11.26 & 2.99 & 8.67 & 13.88
\end{tabular}

SDM: Shoot dry matter; RDM: Root dry matter; NDM: nodules dry matter

Regarding the lack of significant difference in the Mo doses, similar results can be found in the literature for common beans (MATOSO; KUSDRA, 2014), soybeans (Glycine max) (GRIS; CASTRO; OLIVEIRA, 2005), peanuts (CAIRES, 2005), and cowpea beans (LEITE et al., 2009). Several aspects might be involved in the unexpected results found in the present study, such as the micronutrient application through seeds, the survival of the strains when inoculated in the seeds after the Mo application, the chemical and intrinsic characteristics of the soil and even the studied cultivar. In addition, Castro et al. (2017) reported that temperature might negatively influence the nodulation process, especially temperatures higher than $40{ }^{\circ} \mathrm{C}$, which may reflect lower plant growth, as observed in the present study. Considering that the experiment was conducted during summer months in a tropical country under greenhouse condition, this temperature could have been reached. Studies have also shown that the efficiency of biological nitrogen fixation can be affected by varying edaphic conditions, such as nutrient levels, soil type, and management practices (ALAM et al., 2015; DABESSA; ABEBE; BEKELE, 2018).

Studies have shown that the application of Mo through seed or leaf may influence the fixation process. Fullin et al. (1999) found that providing the micronutrient through seed by pelletizing was not efficient. Some studies have revealed that foliar application may show more efficient responses for micronutrient application (FULLIN et al., 1999; YANNI, 1990). In addition, Amara and Nasr (1995) reinforced that better results were obtained when Mo was applied by spraying the leaves, and this higher efficiency of foliar application was corroborated by Lopes et al. (2014, 2016), after finding higher contents of Mo in bean leaves and seeds. However, for soybean, it is currently recommended the application of Mo with the inoculant via seed where Bradyrhizobium strains are inoculated (ALBINO; CAMPO, 2001). Thus, it can be deduced that for cowpea, better answers could have been obtained if foliar fertilization was applied, thus, benefiting the BNF. Other researchers concluded that the seed reserve could provide enough Mo contents to meet the plant's requirement for at least one generation, without compromising the productivity (BRODRICK; GILLER, 1991).

It is known that cowpea beans are able to nodulate with different bacteria species, from different genus such as Rhizobium, Bradyrhizobium and Sinorhizobium (RUMJANEK et al., 2005). Studies previously reported that the species $B$. elkanii (INPA 03 11B), also tested in this study, has shown high efficiency in BNF. However, variations among strains show different values for the $\mathrm{N}$ contents (SOARES et al., 2006; ZILLI et al., 2006). These variations can occur due to the intrinsic characteristics of the organism or by external factors (temperature, for example) and also due to some chemical-molecular aspects involved in the rhizobia-leguminous interaction.

Studies indicate that the application of Mo may cause deleterious effects to the inoculated strains in the seeds of the inoculated culture (CAMPO; ARAÚJO; HUNGRIA, 2009). For example, high doses of Mo may decrease the number of viable cells of Bradyrhizobium strains on the root surface, impairing the biological nitrogen fixation process (TONG; SADOWSKY, 1994). In addition, the survival of Bradyrhizobium may be reduced in liquid inoculants when compared with peat moss (ALBINO; CAMPO, 2001). Therefore, it can be suggested that the inoculants survival can be affected by the application of Mo, when it was applied to seeds.

Tong and Sadowsky (1994) suggested that high doses of Mo affect Bradyrhizobium, and may decrease the number of viable cells on the seed surface, impairing nodulation and biological nitrogen fixation. Albino and Campo (2001) also stated that the application of Mo to soybean via seeds reduced the number of Bradyrhizobium cells due to its contact with the inoculant and, consequently, the nodulation and biological nitrogen fixation. 
The specificity between the host plant and the symbiotic organisms is controlled by the production of bacterial and root exudates (PERRET; STAEHELIN; BROUGHTON, 2000) and by genetic factors. Plant exudates, known as flavonoids, are recognized by bacteria as they are released (FERNANDES JUNIOR; REIS, 2008). On the other hand, microsymbionts produce nod factors as a response, which are important molecular signals recognized by high-affinity receptors in plants that induce responses in the host plant, such as the deformation of the root hairs (DÉNARIÉ; DEBELLÉ; PROMÉ, 1996). Therefore, according to the low fixed $\mathrm{N}$ content through the nodules, the flavonoids could not have been recognized by the inoculated strains.

The establishment of interactions of legumes and rhizobia is coordinated by many other interactions between them. Initially, the nod factors receive the plant flavonoids signals (RIVAS et al., 2009) and, consequently, the nod factors of rhizobia act inducing nodules formation of plants. In this way, all processes involved in BNF, as well as the type and quantity of interactions are important to determine the leguminous-rhizobia specificity (LAGUERRE et al., 2001). Therefore, some of these characteristics might have interfered in the perfect symbiosis and, consequently, on the $\mathrm{N}$ fixation efficiency.

The absence of a response from Mo fertilization can be due to the natural Mo content in the soil, which could be enough to meet the requirements of the plant (FERREIRA et al., 2001). According to Jacob Neto and Rosseto (1998), regarding micronutrients, the seeds' internal reservoir is sufficient to allow plant growth without external dependence. Barbosa et al. (2010) also stated that Mo reservoir in seeds could be enough for a good plant development when they are well supplied with other nutrients. The soil used in this experiment did not show signs of previous cultivation, a fact that could be responsible for Mo exportation and availability decrease. This fact corroborates the hypothesis that the soil may present enough natural Mo contents.

The application of limestone to raise soil $\mathrm{pH}$ is responsible to increase Mo availability, especially Mo ions adsorbed on $\mathrm{Fe}$ and $\mathrm{Al}$ oxides (MARCONDES; CAIRES, 2005). Although Mo is a plant nutrient, especially for the ones that biologically fix atmospheric $\mathrm{N}$, the required content of the nutrient is considered to be low (LEITE et al.,
2007). The $\mathrm{pH}$ adjustment in soils could be enough to increase the Mo availability and supply according the need of the plant, masking the response for different Mo doses. Lantmann et al. (1989) reinforced this idea by stating that Mo addition is closely related to soil $\mathrm{pH}$, with better efficiencies in soils with low $\mathrm{pH}$.

Doses of Mo can be responsible for different responses in plants according to the tested cultivars of a given species. By analyzing the behavior of 17 evaluated beans, Amane et al. (1994) observed that the intensity of their responses to Mo was conflicting. Some cultivars show different behaviors regarding the application of Mo, and a given cultivar may have the same efficiency with the application of Mo both through seeds or leaves. Berger et al. (1995) observed that in the bean cultivar Ouro, there was no differentiated response regarding the form of application. In contrast, in the other tested cultivar, Ouro Negro, the foliar application was more effective than via seed. Alam et al. (2015) conducted a study in which several doses of Mo were applied to the soil to evaluate its effect on nodulation and hairy vetch (Vicia villosa Roth) biomatter production. The application of Mo increased the number and size of nodules and the activity of nitrogenase and nitrate reductase enzymes in plants, leading to increased $\mathrm{N}$ uptake and increased biomatter; in plants grown in soil receiving $0.5 \mathrm{mg}$ of Mo per $\mathrm{kg}$, there was increased $\mathrm{N}$ fixation in hairy vetch (Vicia villosa Roth). Thus, it is important to consider such events when choosing a cultivar to be studied.

Nitrogen fertilization, when analyzed lonely, promoted statistically higher SDM, RDM and $\mathrm{N}$ contents when compared with the treatments with bacteria inoculation (Table 3). Nitrogen accumulations in shoots were also significantly higher in treatments with nitrogen fertilization when compared with treatments with bacteria inoculation, as shown in Figure 1. Broadley et al. (2000) suggested a negative effect in plants with $\mathrm{N}$ deficiency and plants with normal $\mathrm{N}$ availability, and this effect can be noticed by the reduction of fresh leaves matter, in limiting conditions for $\mathrm{N}$.

Regarding the highest production of dry matter in treatments with $\mathrm{N}$ fertilization when compared with bacteria inoculation, it can be considered that it is metabolically less expensive for plants to use $\mathrm{N}$ that is readily available in soil than to establish an association with diazotrophic bacteria (GYANESHWAR et al., 2002). 
Table 3. Mean tests for treatments with nitrogen addition and treatments with bacteria inoculation.

\begin{tabular}{cccc}
\hline \multirow{2}{*}{ Treatments } & \multicolumn{3}{c}{ Means } \\
\cline { 2 - 4 } & SDM & RDM & N content \\
\hline Nitrogen fertilization & $2.62 \mathrm{a}$ & $1.01 \mathrm{a}$ & $8.79 \mathrm{a}$ \\
Bacteria inoculation & $1.61 \mathrm{~b}$ & $0.90 \mathrm{~b}$ & $5.85 \mathrm{~b}$ \\
\hline
\end{tabular}

Means followed by the same letters do not differ from each other by the Scott Knott Test with 5\% probability. SDM: Shoot dry matter, RDM: root dry matter and $\mathrm{N}$ content: $\mathrm{N}$ foliar content.

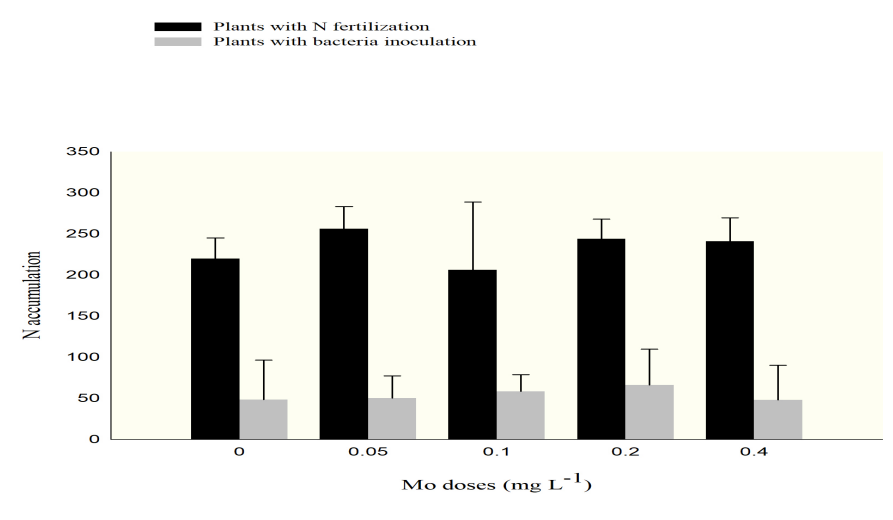

Figure 1. Nitrogen accumulation with different Mo doses in treatments with $\mathrm{N}$ fertilization compared with treatments with bacteria inoculation

Nitrogen is one of the responsible nutrients for plants growth and for production of new tissues and cells, influencing IAA (indolyl acetic acid) synthesis, which is the plant growth hormone (FAQUIN; ANDRADE, 2004). That is why, in this study, higher contents of $\mathrm{N}$ can result in higher matter production.

According to Malavolta, Vitti and Oliveira (1997), reference values for foliar $\mathrm{N}$ content in beans ranges from 3 to $5 \mathrm{dag} \mathrm{kg}^{-1}$ ( 30 to $50 \mathrm{~g} \mathrm{~kg}^{-1}$ ). Considering that the average $\mathrm{N}$ contents in the inoculated treatments and in the fertilized treatments were 34.4 and $77 \mathrm{~g} \mathrm{~kg}^{-1}$, respectively, the BNF was sufficient to reach this reference range.

In general, one can state that, in some way, such factors may have influenced the biological nitrogen fixation process, which contributes to the effects on the application of different doses of Mo in the soils that have their $\mathrm{pH}$ adjusted. All treatments that presented nodules were the ones inoculated with bacteria. No nodule was observed in treatments with nitrogen fertilization, confirming that there was not contamination among treatments.

\section{CONCLUSIONS}

No significant results were found for Mo application for each tested dose. Therefore, it was not possible to determine the adequate dose to improve and benefit BNF.

Many factors, such as the form of Mo application, the strains, the soil characteristics, as well as the studied cultivar might have contributed to low BFN and the no effect found after Mo application.

This study was the first step in understanding how Mo can be applied to improve the biological nitrogen fixation. 


\section{ACKNOWLEDGEMENTS}

The authors would like to thank the financial support from the National Council of Technology and Scientific Development (CNPq),
Coordination for the Improvement of Higher Education Personnel (CAPES) and the Foundation for Research Support of the Minas Gerais State (FAPEMIG).

RESUMO: Em algumas plantas de leguminosas, as associações com microorganismos de fixação permitem a sua nutrição com N (nitrogênio) da atmosfera. Este processo é conhecido como Fixação Biológica de Nitrogênio (FBN), onde através de enzimas nitrogenase $\mathrm{N}_{2}$ é convertido na forma disponível. Este processo pode substituir em parte, ou no total, fertilizantes nitrogenados. O feijão-caupi é uma espécie de leguminosa que é reconhecida pela sua alta capacidade de FBN. Nas últimas décadas, estudos encorajaram os pequenos agricultores do norte e nordeste do Brasil a usar inoculantes com espécies de rizobio, uma vez que os resultados das pesquisas têm demonstrado que a inoculação é uma estratégia interessante para melhorar a produção dessa cultura. Considerando a função específica do molibdênio (Mo) na assimilação do N, diferentes doses de Mo foram testadas neste estudo, a fim de encontrar doses que possam melhorar e potencializar a FBN. A inoculação foi feita com as estirpes UFLA 03-84 e INPA 03-11B. As diferentes doses de Mo foram aplicadas na semente, cinco sementes por vaso. Trinta e cinco dias após a germinação, as plantas foram analisadas com relação à matéria seca aérea e radicular, teor de $\mathrm{N}$ e acúmulo, índice de análise de desenvolvimento solo-planta (SPAD) e nodulação nas plantas inoculadas. As diferentes doses de Mo não mostraram diferenças significativas no conteúdo de $\mathrm{N}$, nem no processo de nodulação. As plantas com adubação nitrogenada tiveram mattera seca da parte aérea e de raízes superior as inoculadas, além de maiores teores foliares de N. Portanto, para feijãocaupi, a FBN não foi tão eficiente quanto o fertilizante nitrogenado nas condições experimentais avaliadas.

PALAVRAS CHAVE: Vigna unguiculata L.. Micronutriente. Bradyrhizobium.

\section{REFERENCES}

ALAM, F. et al. Effect of molybdenum on nodulation, plant yield and nitrogen uptake in hairy vetch (Vicia villosa Roth). Soil Science and Plant Nutrition, Tokio, v. 61, n. 4, p. 664-675, Apr. 2015. https://doi.org/10.1080/00380768.2015.1030690

ALBINO, U. B.; CAMPO, R. J. Efeito de fontes e doses de molibdênio na sobrevivência do Bradyrhizobium e na fixação biológica de nitrogênio em soja. Pesquisa Agropecuária Brasileira, Brasília, v. 36, n. 3, p. 527534, mar. 2001. https://doi.org/10.1590/S0100-204X2001000300018

ALVARES, C. A. et al. Köppen's climate classification map for Brazil. Meteorologische Zeitschrift, Berlin, v. 22, n. 6, p. 711-728, Dec. 2013. https://doi.org/10.1127/0941-2948/2013/0507

AMANE, M. I. V. et al. Resposta de cultivares de feijão (Phaseolus vulgaris L.) às adubações nitrogenada e molíbdica. Revista Ceres, Viçosa, v. 41, n. 234, p. 202-216, 1994.

AMARA, A. M.; NASR, S. A. Impact foliar application with biofertilizers and micronutrients on the growth and yield of Bradyrhizobium inoculated soybean plants. Annals of Agricultural Science, Cairo, v. 40, n. 2, p. 567-578, 1995.

ANTUNES, F. Z. Caracterização climática do estado de Minas Gerais. Informe Agropecuário, Belo Horizonte, v. 12, n. 139, p. 9-13, 1986.

BARBOSA, G. F. et al. Nitrogênio em cobertura e molibdênio foliar no feijoeiro de inverno. Acta

Scientiarum. Agronomy, Maringá, v. 32, n. 1, p. 117-123, jan./mar. 2010.

https://doi.org/10.4025/actasciagron.v32i1.1605 
BERGER, P. G. et al. Peletização de sementes de feijão (Phaseolus vulgaris L.) com carbonato de cálcio, rizóbio e molibdênio. Revista Ceres, Viçosa, v. 42, n. 243, p. 562-574, set./out. 1995.

BOYDSTON, R. A. et al. The impact of tillage on pinto bean cultivar response to drought induced by deficit irrigation. Soil and Tillage Research, Amsterdam, v. 180, p. 63-72, Aug. 2018.

https://doi.org/10.1016/j.still.2018.02.011

BROADLEY, M. R. et al. Function of nutrients: micronutrients. In: MARSCHNER, P. Marschner's mineral nutrition of higher plants. Amsterdam: Elsevier, 2012. chap. 7, p. 191-248.

. What are the effects of nitrogen deficiency on growth components of lettuce? New Phytologist, Cambridge, v. 147, n. 3, p. 519-526, Sept. 2000. https://doi.org/10.1046/j.1469-8137.2000.00715.x

BRODRICK, S. J.; GILLER, K. E. Root nodules of Phaseolus: efficient scavengers of molybdenum for N2fixation. Journal of Experimental Botany, Oxford, v. 42, n. 238, p. 679-686, May 1991.

https://doi.org/10.1093/jxb/42.5.679

CAMPO, R. J.; ARAÚJO, R. S.; HUNGRIA, M. Molybdenum-enriched soybean seeds enhance N accumulation, seed yield, and seed protein content in Brazil. Field Crops Research, Amsterdam, v. 110, n. 3, p. 219-224, Feb. 2009. https://doi.org/10.1016/j.fcr.2008.09.001

CASTRO, J. L. de et al. Diversity and efficiency of rhizobia communities from iron mining áreas using cowpea as a trap plant. Revista Brasileira de Ciência do Solo, Viçosa, v. 41, p. 1-20, ago. 2017.

https://doi.org/10.1590/18069657rbcs20160525

COOPER, J. E.; SCHERER, H. W. Nitrogen fixation. In: MARSCHNER, P. Marschner's mineral nutrition of higher plants. Amsterdam: Elsevier, 2012. chap. 16, p. 389-408. https://doi.org/10.1016/B978-0-12384905-2.00016-9

COSTA, E. M. da et al. Bradyrhizobium brasiliense sp. Nov., a symbiotic nitrogen-fixing bacterium isolated from Brazilian tropical soils. Archives of Microbiology, Berlin, v. 199, n. 8, p. 1211-1221, Oct. 2017 a. https://doi.org/10.1007/s00203-017-1390-1

. Classification of the inoculant strain of cowpea UFLA03-84 and of other strains from soils of the Amazon region as Bradyrhizobium viridifuturi symbiovar tropici. Brazilian Journal of Microbiology, Rio de Janeiro, v. 50, n. 2, p. 335-345, abr. 2019. https://doi.org/10.1007/s42770-019-00045-x

. Lima bean nodulates efficiently with Bradyrhizobium strais isolated from diverse legume species. Symbiosis, Philadelphia, v. 73, n. 2, p. 125-133, Oct. 2017b. https://doi.org/10.1007/s13199-017-0473-8

Resposta de duas cultivares de feijão-caupi à inoculação com bactérias fixadoras de nitrogênio em

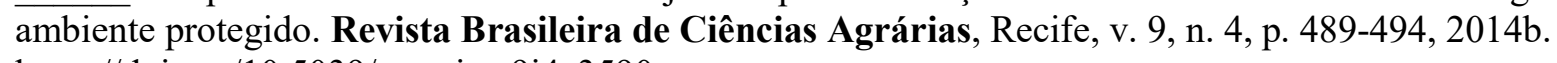
https://doi.org/10.5039/agraria.v9i4a3590

. Growth and yield of the cowpea cultivar BRS Guariba inoculated with rhizobia strains in southwest Piauí. Semina: ciências agrárias, Londrina, v. 35, n. 6, p. 3073-3084, nov./dez. 2014a. https://doi.org/10.5433/1679-0359.2014v35n6p3073

DABESSA, A.; ABEBE, Z.; BEKELE, S. Limitations and strategies to enhance biological nitrogen fixation in sub-humid tropics of Western Ethiopia. Journal of Agricultural Biotechnology and Sustainable Development, Nairobi, v. 10, n. 7, p. 122-131, July 2018. https://doi.org/10.5433/1679-0359.2014v35n6p3073 
DÉNARIÉ, J.; DEBELLÉ, F.; PROMÉ, J. C. Rhizobium lipo-chitooligosaccharide nodulation factors: signaling molecules mediating recognition and morphogenesis. Annual Review of Biochemistry, Palo Alto, v. 65, p. 503-535, 1996. https://doi.org/10.1146/annurev.bi.65.070196.002443

FAQUIN, V.; ANDRADE, A. T. Nutrição mineral e diagnose do estado nutricional das hortaliças. Lavras: UFLA/FAEPE, 2004. 88 p.

FARIAS, T. P. et al. Eficiência simbiótica de estirpes de rizóbio em Feijão-Caupi no sul do Maranhão. Revista Caatinga, Mossoró, v. 29, n. 3, p. 611-618, jul./set. 2016.

FERNANDES JUNIOR, P. I.; REIS, V. M. Algumas limitações à fixação biológica de nitrogênio em leguminosas. Seropédica: Embrapa Agrobiologia, 2008. 33 p.

FERREIRA, A. C. de B. et al. Características agronômicas e nutricionais do milho adubado com nitrogênio, molibdênio e zinco. Scientia Agrícola, Piracicaba, v. 58, n. 1, p. 131-138, jan./mar. 2001.

https://doi.org/10.1590/S0103-90162001000100020

FERREIRA, D. F. Sisvar: a computer statistical analysis system. Ciência e Agrotecnologia, Lavras, v. 35, n. 6 , p. 1039-1042, nov./dez. 2011. https://doi.org/10.1590/S1413-70542011000600001

FERREIRA, L. de V. M. et al. Biological nitrogen fixation in production of Vigna unguiculata (L.) walp, family farming in Piauí, Brazil. Journal of Agricultural Science, Ottawa, v. 5, n. 4, p. 153-160, 2013. https://doi.org/10.5539/jas.v5n4p153

FREIRE FILHO, F. R. et al. Melhoramento genético. In: Brasília: Embrapa Informação Tecnológica, 2005. cap. 1, p. 28-92.

(Org.). Feijão Caupi: avanços tecnológicos.

FULLIN, E. A. et al. Nitrogênio e molibdênio na adubação do feijoeiro irrigado. Pesquisa Agropecuária Brasileira, Brasília, v. 34, n. 7, p. 1145-1149, jul. 1999. https://doi.org/10.1590/S0100-204X1999000700005

GRIS, E. P.; CASTRO A. M. C. e; OLIVEIRA, F. F. de. Produtividade da soja em resposta à aplicação de molibdênio e inoculação com Bradyrhizobium japonicum. Revista Brasileira de Ciência do Solo, Viçosa, v. 29, n. 1, p. 151-155, jan./fev. 2005. https://doi.org/10.1590/S0100-06832005000100017

GUIMARÃES, A. A. et al. High diversity of Bradyrhizobium strains isolated from several legume species and land uses in Brazilian tropical ecosystems. Systematic and Applied Microbiology, Stuttgart, v. 38, n. 6, p. 433-441, Sept. 2015. https://doi.org/10.1016/j.syapm.2015.06.006

GUPTA, U. C.; LIPSETT, J. Molybdenum in soil, plants and animals. Advances in Agronomy, San Diego, v. 34, p. 73-115, 1981. https://doi.org/10.1016/S0065-2113(08)60885-8

GYANESHWAR, P. et al. Herbaspirillum colonization increases growth and nitrogen accumulation in aluminium-tolerant rice varieties. New Phytologist, Cambridge, v. 154, n. 1, p. 131-145, Apr. 2002. https://doi.org/10.1046/j.1469-8137.2002.00371.x

JACOB-NETO, J.; THOMAS, R. J.; FRANCO, A. A. Variação estacional da concentração de molibdênio nos nódulos e demais partes da planta de feijoeiro (Phaseolus vulgaris L.). Turrialba, San José, v. 38, p. 51-58, 1988.

JACOB-NETO, J.; ROSSETO, C. A. V. Concentração de nutrientes nas sementes: o papel do molibdênio. Floresta e Ambiente, Seropédica, v. 5, n. 1, p. 171-183, jan./dez. 1998.

KUBOTA, F. Y. Aumento dos teores de fósforo e de molibdênio em sementes de feijoeiro (Phaseolus vulgaris L.) via adubação foliar. 2006. 58 f. Dissertação (Mestrado em Ciências Agrárias) - Universidade Federal Rural do Rio de Janeiro, Rio de Janeiro, 2006. 
LAGUERRE, G. et al. Classification of rhizobia based on nodC and nifH gene analysis reveals a close phylogenetic relationship among Phaseolus vulgaris symbionts. Microbiology, Washington, v. 147, n. 4, p. 981-993, Apr. 2001. https://doi.org/10.1099/00221287-147-4-981

LANTMANN, A. F. et al. Resposta da soja a molibdênio em diferentes níveis de pH do solo. Revista Brasileira de Ciência do Solo, Campinas, v. 13, n. 1, p. 45-49, jan./abr. 1989.

LEITE, U. T. et al. Rendimento de grãos e componentes de rendimento do feijoeiro em função da aplicação foliar de doses crescentes de molibdênio. Acta Scientiarum. Agronomy, Maringá, v. 29, n. 1, p. 113-120, mar. 2007. https://doi.org/10.4025/actasciagron.v29i1.74

LEITE, L. F. C. et al. Nodulação e produtividade de grãos do feijão-caupi em resposta ao molibdênio. Revista Ciência Agronômica, Fortaleza, v. 40, n. 4, p. 492-497, out./dez. 2009.

LIMA, A. S.; PEREIRA. J. P. A. R.; MOREIRA, F. M. de S. Diversidade fenotípica e eficiência simbiótica de estirpes de Bradyrhizobium spp. de solos da Amazônia. Pesquisa Agropecuária Brasileira, Brasília, v. 40, n. 11, p. 1095-1104, nov. 2005. https://doi.org/10.1590/S0100-204X2005001100007

LOPES, J. F. et al. Adubação foliar com níquel e molibdênio no feijoeiro comum cv. Ouro Vermelho. Revista Ceres, Viçosa, v. 61, n. 2, p. 234-240, abr. 2014. https://doi.org/10.1590/S0034-737X2014000200011

Produtividade e composição mineral do feijão em resposta às adubações com molibdênio e níquel.

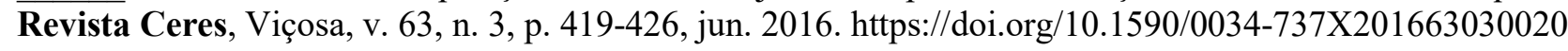

MA, J. et al. Impacts of Mo Application on biological nitrogen fixation and diazotrophic communities in a flooded rice-soil system. Science of the Total Environment, Amsterdam, v. 649, p. 686-694, Feb. 2018. https://doi.org/10.1016/j.scitotenv.2018.08.318

MALAVOLTA, E. Elementos de nutrição mineral de plantas. São Paulo: Agronômica Ceres, 1980. 251 p.

MALAVOLTA, E.; VITTI, G. C.; OLIVEIRA, S. A. de. Avaliação do estado nutricional das plantas: princípios e aplicações. Piracicaba: Potafós, 1997. 319 p.

MARCONDES, J. A. P.; CAIRES, E. F. Aplicação de molibdênio e cobalto na semente para cultivo da soja. Bragantia, Campinas, v. 64, n. 4, p. 687-694, 2005. https://doi.org/10.1590/S0006-87052005000400019

MATOSO, S. C. G.; KUSDRA, J. F. Nodulação e crescimento do feijoeiro em resposta à aplicação de molibdênio e inoculante rizobiano. Revista Brasileira de Engenharia Agrícola e Ambiental, Campina Grande, v. 18, n. 6, p. 567-573, 2014. https://doi.org/10.1590/S1415-43662014000600001

PERRET, X.; STAEHELIN, C.; BROUGHTON, W. J. Molecular basis of symbiotic promiscuity. Microbiology and Molecular Biology Reviews, Washington, v. 64, n. 1, p. 180-201, Mar. 2000. https://doi.org/10.1128/MMBR.64.1.180-201.2000

RIVAS, R. et al. Multilocus sequence analysis of the genus Bradyrhizobium. Systematic and Applied Microbiology, Stuttgart, v. 32, n. 2, p. 101-110, Apr. 2009. https://doi.org/10.1016/j.syapm.2008.12.005

RUFINI, M. et al. Bradyrhizobium spp. Strains in symbiosis with pigeon pea cv. fava-larga under greenhouse an field conditions. Revista Brasileira de Ciência do Solo, Viçosa, v. 40, p. 1-14, 2016. https://doi.org/10.1590/18069657rbcs20160156

RUMJANEK, N. G. et al. Fixação biológica de nitrogênio. In: FREIRE FILHO, F. R. et al. (Ed.). Feijão Caupi: avanços tecnológicos. Brasília: Embrapa Informação Tecnológica, 2005. p. 281-335. 
SIMIL, F. F. et al. Study of the chemical composition of Urochloa brizantha using the SPAD index, neural networks, multiple linear models, principal components and cluster analysis. Animal Feed Science and Technology, Amsterdam, Oct. 2019. Disponível em: <https://www.sciencedirect.com/science/article/ pii/S0377840119302433>. Acesso em: 12 ago. 2019.

SOARES, A. L. de L. et al. Eficiência agronômica de rizóbios selecionados e diversidade de populações nativas nodulíferas em Perdões (MG): I. Caupi. Revista Brasileira de Ciência do Solo, Viçosa, v. 30, n. 5, p. 795-802, set./out. 2006. https://doi.org/10.1590/S0100-06832006000500005

SOARES, B. L. et al. Agronomic and economic efficiency of common-bean inoculation with rhizobia and mineral nitrogen fertilization. Revista Brasileira de Ciência do Solo, Viçosa, v. 40, p. 1-13, ago. 2016. https://doi.org/10.1590/18069657rbcs20150235

TONG, Z.; SADOWSKY, M. J. A selective medium for the isolation and quantification of Bradyrhizobium japonicum and Bradyrhizobium elkanii strains from soils and inoculants. Applied and Environmental Microbiology, Washington, v. 60, n. 2, p. 581-586, Feb. 1994.

VIEIRA, C. L. et al. Inoculação de variedades locais de feijão macassar com estirpes selecionados de rizóbio. Revista Brasileira de Engenharia Agrícola e Ambiental, Campina Grande, v. 14, n. 11, p. 1170-1175, nov. 2010. https://doi.org/10.1590/S1415-43662010001100006

VINCENT, J. M. Manual for the practical study of root-nodule bacteria. Oxford: Blackwell Scientific, 1970. $164 \mathrm{p}$.

YANNI, Y. G. Response of symbiotic interrelationship between soybean and the indigenous or inoculated microsymbiont, Bradyrhizobium japonicum, to soil application of manganese and molybdenum. World Journal of Microbiology \& Biotechnology, Oxford, v. 6, n. 3, p. 289-294, Sept. 1990. https://doi.org/10.1007/BF01201299

ZILLI, J. E. et al. Eficiência simbiótica de estirpes de Bradyrhizobium isoladas de solo do Cerrado em caupi. Pesquisa Agropecuária Brasileira, Brasília, v. 41, n. 5, p. 811-818, maio 2006. https://doi.org/10.1590/S0100-204X2006000500013. 